\title{
MYCBP2 Gene
}

National Cancer Institute

\section{Source}

National Cancer Institute. MYCBP2 Gene. NCI Thesaurus. Code C88941.

This gene may play a role in both ubiquitination and transcriptional regulation. 